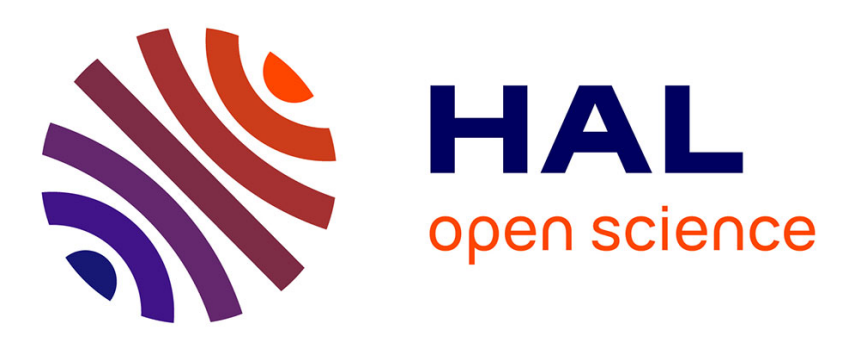

\title{
Anandamide modulates growth and lipid metabolism in the zebrafish
}

B. Migliarini, O. Carnevali

\section{To cite this version:}

B. Migliarini, O. Carnevali. Anandamide modulates growth and lipid metabolism in the zebrafish. Molecular and Cellular Endocrinology, 2008, 286 (1-2), 10.1016/j.mce.2008.01.021 . hal-00531990

\section{HAL Id: hal-00531990 \\ https://hal.science/hal-00531990}

Submitted on 4 Nov 2010

HAL is a multi-disciplinary open access archive for the deposit and dissemination of scientific research documents, whether they are published or not. The documents may come from teaching and research institutions in France or abroad, or from public or private research centers.
L'archive ouverte pluridisciplinaire HAL, est destinée au dépôt et à la diffusion de documents scientifiques de niveau recherche, publiés ou non, émanant des établissements d'enseignement et de recherche français ou étrangers, des laboratoires publics ou privés. 


\section{Accepted Manuscript}

Title: Anandamide modulates growth and lipid metabolism in the zebrafish Danio rerio

Authors: B. Migliarini, O. Carnevali

PII: $\quad$ S0303-7207(08)00019-1

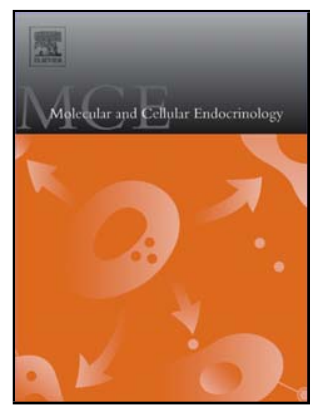

DOI: doi:10.1016/j.mce.2008.01.021

Reference: MCE 6797

To appear in: Molecular and Cellular Endocrinology

Received date:

15-12-2007

Revised date:

$18-1-2008$

Accepted date:

19-1-2008

Please cite this article as: Migliarini, B., Carnevali, O., Anandamide modulates growth and lipid metabolism in the zebrafish Danio rerio, Molecular and Cellular Endocrinology (2007), doi:10.1016/j.mce.2008.01.021

This is a PDF file of an unedited manuscript that has been accepted for publication. As a service to our customers we are providing this early version of the manuscript. The manuscript will undergo copyediting, typesetting, and review of the resulting proof before it is published in its final form. Please note that during the production process errors may be discovered which could affect the content, and all legal disclaimers that apply to the journal pertain. 
TITLE: Anandamide modulates growth and lipid metabolism in the zebrafish Danio rerio

Migliarini B. and Carnevali O. *

Department of Marine Sciences

Università Politecnica delle Marche

Via Brecce Bianche 60131, Ancona, Italy

${ }^{*}$ CORRESPONDING AUTHOR:

Prof. Oliana Carnevali

Dipartimento di Scienze del Mare, Università Politecnica delle Marche,

Tel:+39-071-2204990 Fax: +39-071-2204650

E-mail: o.carnevali@univpm.it 


\section{SUMMARY}

Endocannabinoids are known to be lipidic mediators with several biological functions as the stimulation of food intake and lipid metabolism via cannabinoid receptor CB1. Many evidences, such as the presence of $C B 1$ mRNA in fat tissue, suggest a peripheral role for endocannabinoids in regulating lipogenesis and body weight in mammals.

As animal models constitute good tools to study endocannabinoid system dynamics, we analyzed the role of the endocannabinoid anandamide (AEA) in modulating lipid metabolism and growth in zebrafish larvae and adults.

The data obtained indicated that AEA administered via water modulates the transcription of its own receptor $C B 1$, besides to up-regulate gene expression of sterol regulatory element binding protein (SREBP) and of the insulin-like growth factors (IGF-1 and IGF-2). The results here obtained represent the first evidence in fish of the endocannabinoid system involvement in lipid metabolism and growth.

Key words: endocannabinoids, AM251, CB1, IGFs, SREBP 


\section{INTRODUCTION}

During the last few years many different regulatory actions have been attributed to the endocannabinoid system.

Endogenous cannabinoids act at CB1 level stimulating appetite and inducing the increase of body weight (Seeley and Woods, 2003). Maintenance of body weight and energy homeostasis requires the coordinated regulation of appetite behaviour and peripheral energy metabolism as demonstrated by the ability of the endocannabinoid system to interact with leptin, the appetite-reducing hormone, insulin and cholesterol in regulating fat metabolism (Ravinet et al., 2003).

A study conducted on obesity in mice showed that a chronic blockage of CB1 receptor induces a significant reduction in fat mass respect to muscular mass (Ravinet et al., 2003; Poirier et al., 2005), leading to confirm what found by Kunos and collaborators who defined the endocannabinoids as "novel lipid mediators" (2002).

Knock out mice for $C B 1$ fed on a standard diet since birth, resulted to be leaner respect to wild type fed at the same manner (Ravinet et al., 2004).

Moreover Liu and collaborators (2005) suggested that the anorexigenic effect of AEA antagonist, besides to act on weight and fat mass decrease, also prevents peripheral stimulatory action of endocannabinoids on lipogenesis and fat accumulation.

This hypothesis was supported by the finding of CB1 receptor in mammalian adipocites whose stimulation brings to lipases activation (Cota et al., 2003), while its blockage brings to the up regulation of adiponectin, a crucial hormone for the inhibition of enzymes involved in lipogenesis (Bensaid et al., 2003; Poirier et al., 2005).

At peripheral level other tissues as liver, pancreas and skeletal muscle are also involved in energy balance cannabinoid system-mediated. In particular, at hepatic level, CB1 receptor stimulation brings to an increase of fatty acid synthesis through the enhancement of SREBP and its target genes (acetil-CoA carboxilase, fatty acid synthase) expression 
(Osei-Hyiaman et al., 2005). CB1 activates fatty acid synthase also in the hypothalamus and receptors for the adiponectin were found also in the nucleus paraventricularis demonstrating that the modulation of energy balance is under the endocannabinoid control passing through a cross talk between hypothalamus and peripheral tissues (Qi et al., 2004; Lichtman and Benjamin, 2005).

To date, the role of the endocannabinoid system in lipid metabolism and growth were studied mainly on mammals, especially on rodents. In order to have a greater understanding of the basic and conserved physiological functions controlled by the endocannabinoid system, that shows high similarities among vertebrates (McPartlandand et al., 2006), zebrafish may represent a good experimental model to study these items, since its full genome availability and its easy breeding and maintenance.

The aim of this paper was, indeed, to explore AEA effects on the expression of $C B 1$ and genes involved in growth and lipid metabolism in zebrafish larvae and adults. Regarding CB1 expression, we also tested the effect of one of its antagonist, the AM251

The data obtained also showed, for the first time, the effect of AEA administration via water on target genes in whole larvae and adult liver.

\section{MATERIALS AND METHODS}

\section{Zebrafish exposure to AEA and AM251}

Three groups of 50 larvae each were performed at 72 hours post fertilization (hpf), corresponding to hatching time, and at 7 and 15 days post fertilization (dpf). The first group was used as control, the second was exposed to AEA $10 \mathrm{nM}$ (dose was chosen on the bases of preliminary studies) for two hours and the third to AM251 $10 \mathrm{nM}$ for two hours followed by two hours of AEA $10 \mathrm{nM}$. All the samples were stored at $-80^{\circ} \mathrm{C}$ for the 
biomolecular analysis.

Adult zebrafish were instead divided into four experimental groups of 10 fish each: the control group, two groups exposed to AEA, 10 and $100 \mathrm{nM}$ respectively, for two hours and the last group exposed to AM251 $10 \mathrm{nM}$ (doses were chosen on the bases of preliminary studies) for the same period. Zebrafish were then anesthetized and the livers were sampled and stored at $-80^{\circ} \mathrm{C}$ until use for biomolecular analysis.

The procedures were performed in accordance with the Guidelines on the handling and Training of Laboratory Animals by the Universities Federation for Animal Welfare (UFAW) and with the Italian animal welfare legislation (D.L. 116/92).

\section{RNA extraction and cDNA synthesis}

Total RNA was extracted from $72 \mathrm{hpf}, 7 \mathrm{dpf}, 15 \mathrm{dpf}$ and liver of adult fish with RNeasy Mini Kit (250) (Quiagen). First strand cDNA synthesis was performed as already described in Migliarini et al. (2006).

\section{Real time PCR}

A relative quantification of $C B 1, I G F-1, I G F-2$ and $S R E B P$ gene expression was made by Real time PCR using the acidic ribosomal protein (ARP) as internal standard. In order to amplify these genes, the following primer pairs were designed: FCB1: 5'TCTGTGGGAAGCCTGTTT-3', RCB1: 5'-ACCGAGTTGAGCCGTTTG-3', FIGF-1: 5'GGCAAATCTCCACGATCTCTAC-3', R/GF-1: 3'-CGGTTTCTCTTGTCTCTCTCAG-5', FIGF-2: 5'- GAGTCCCATCCATTCTGTTG-3', RIGF-2: 3'-TCCTTTGTTTGTTGCCATTTG-

5', FSREBP: 5'-GCTGTTACCCTCTGCTGAAG-3', RSREBP: 5'TGAAACCGCTGCCTTGAC-3'.

ARP was amplified using the following primers: FARP: 5'-TTCCTCGGTATGGAGTCCT-3', RARP: 5'-TGGGGCAATGATCTTGATCTT-3'. 
The Real Time PCRs were performed with SYBR green method in a iQ5 Multicolor RealTime PCR Detection system (BioRad). Triplicate PCR reactions were carried out for each sample analyzed.

The reactions were set on a 96-well plate by mixing, for each sample, $1 \mu \mathrm{l}$ of diluted $(1 / 10)$ cDNA, $5 \mu$ l of $2 X$ concentrated SYBR Green PCR Master Mix (BioRad), containing SYBR Green as fluorescent intercalating agent, $0,3 \mu \mathrm{M}$ forward primer and $0,3 \mu \mathrm{M}$ of reverse primer. The thermal profile for all reactions was $3 \min 95^{\circ} \mathrm{C}$ and then 45 cycles of $10 \mathrm{~s}$ at $95^{\circ} \mathrm{C}, 20 \mathrm{~s}$ at $60^{\circ} \mathrm{C}$ and $20 \mathrm{~s}$ at $72^{\circ} \mathrm{C}$. The fluorescence monitoring occurred at the end of each cycle.

Additional dissociation curve analysis was performed and showed in all cases one single peak.

Data obtained were treated by iQ5 optical system software version 2.0.

\section{RESULTS}

\section{CB1 gene expression}

The exposure of zebrafish larvae to AEA significantly up regulated $C B 1$ gene expression in all the developmental stages analyzed: $72 \mathrm{hpf}$ (hatching time), $7 \mathrm{dpf}$ and $15 \mathrm{dpf}$ (Fig. 1). Similar results were obtained in the liver of adult zebrafish, after AEA in vivo exposure, with the highest dose of the endocannabinoid (Fig. 2).

For what concern CB1 gene expression, the effect of a CB1 antagonist, AM251, was also evaluated in the three developmental stages here studied, as well as in adult liver. AM251 significantly down regulated CB1 transcription in larvae and in adult liver (Fig. 1-2). 


\section{IGF-1 and IGF-2 gene expression}

Zebrafish larvae exposed to AEA at $72 \mathrm{hpf}$ (hatching time), $7 \mathrm{dpf}$ and $15 \mathrm{dpf}$ showed a significant increase of IGF-1 gene expression respect to controls (Fig. 3). As regard IGF-2, the same results were evident for 7 and $15 \mathrm{dpf}$ larvae while no significant differences were measurable at hatching time respect to control (Fig. 4). The effect of AEA on zebrafish larvae IGF-1 and IGF-2 gene expression was the same detected in adult zebrafish liver. In particular, both doses of AEA were effective on IGF-1 expression while only the highest dose provoked a significant up regulation on IGF-2 (Fig. 5).

\section{SREBP gene expression}

SREBP gene expression was up regulated by AEA exposure in zebrafish larvae at $7 \mathrm{dpf}$ and $15 \mathrm{dpf}$, while no significant changes between larvae exposed to AEA and controls were measurable at $72 \mathrm{hpf}$ (hatching time) (Fig. 6). In the liver of the adult zebrafish, only the exposure to the highest dose of AEA induced a significant increase of SREBP gene expression respect to controls (Fig. 7).

\section{DISCUSSION}

Animal models are considered from decades ideal tools for elucidating the role of exogenous and endogenous cannabinoids in the control of energy metabolism (Huy et al., 1975; McLaughlin et al., 1979; Guzman et al., 1995; Cota et al., 2003).

Contradictory results were obtained depending on the species and the doses of the cannabinoids administered, but it is currently known that the role of the endocannabinoid in the regulation of food responses and energy metabolism presents a high degree of evolutionary conservation.

A recent study conducted on mice indicated that the endocannabinoid system controls energy homeostasis via both central orexigenic and peripheral lipogenic mechanisms. 
Moreover, they found that in young $C B 1-1-$ mice, the lean phenotype is predominant caused by decreased caloric intake whereas, in adult CB1-I- mice, metabolic factors appear to contribute to the lean phenotype (Cota et al., 2003).

In this paper we focused on the endocannabinoid AEA effects, mediated by its receptor CB1, on the peripheral lipogenic mechanisms as well as on growth in adult zebrafish liver and in different zebrafish developmental stages starting from hatching.

We first intended to study AEA ability, administered via water, to modulate the gene expression of its own receptor $C B 1$, and we found that this endocannabinoid up regulates CB1 transcription as it is well known for other lipophilic molecules such as steroid hormones (i.e. estrogens, androgens and cortisol) able to modulate their own receptors gene expression (Pottinger 1990; Dai and Burnstein, 1996; Meucci and Arukwe 2006; Mortensen and Arukwe 2007). As there are not previous evidences in literature proving the effects of endocannabinoid administration via water, these results provide a very interesting evidence on AEA capability to pass zebrafish larval skin and to target adult liver, modulating the transcription of $C B 1$ from early life cycle to adult life. In adults, the up regulation of $C B 1$ mRNA occurs with a 10 fold higher AEA dose, respect to larvae.

CB1 down regulation, operated by the antagonist AM251, proved that its modulation by AEA occurs via the CB1-AEA complex as usually evidenced for many lipophilic signals. As it is known that in $C B 1-/-$ mice the levels of the lipogenic factor SREBP gene expression are consistently lower respect to $C B 1+/+($ Osei-Hyaman et al., 2005), we then analyzed its transcription levels modulation by AEA. Besides CB1 expression increase, our results showed that this endogenous cannabinoid, via water, also up regulates SREBP. This result is in agreement with previous data obtained in mammals demonstrating that SREBP induction is enhanced by $C B 1$ up-regulation (Osei-Hyaman et al., 2005). More specifically, we found that in the adult fish liver, only the highest dose of the endocannabinoid resulted in the up regulation of SREBP expression. Regarding the 
zebrafish developmental stages, AEA became effective on SREBP expression at $7 \mathrm{dpf}$ and $15 \mathrm{dpf}$. No effect was evident at hatching time when the small larvae were not ready to eat by themselves and the energies were supplied by the yolk sack.

Moreover, we analyzed the expression of two factors belonging to the insulin growth factor system: IGF-1 and IGF-2, known to be secreted by adult liver and to target muscles for cell proliferation (Jones and Clemmons, 1995; Chen et al., 1998). The IGFs are also responsible for embryo and larval growth during development (Carnevali et al., 2005).

In this study, as regards the endocannabinoid system control of growth, the IGF-1 and IGF-2 were found to be up regulated by AEA with the exception for hatching stage where this endocannabinoid resulted ineffective.

The increase of IGFs gene expression may be due to peroxisome proliferator activated receptors (PPARs) $\alpha$ and $\gamma$, known to be involved in lipid metabolism and cell proliferation and development (Braissant and Wahali, 1997; Fu et al., 2005; Grimaldi, 2007), as IGF-1 is one of PPARs target genes (Villeneuve, 2004). Interestingly, recent studies also described the induction of PPAR $\alpha$ and $\gamma$ by AEA (Burstein 2005; Russo et al., 2007). These last results further on confirmed that AEA, administered via water, modulates the expression of target genes and showed, for the first time, a potential relation between the endocannabinoid system and IGFs in fish.

It is thus possible to conclude that the results reported in this study altogether constitute a starting point for better understanding the role of the endocannabinoid system in growth and cellular proliferation, besides to represent a useful contribution in the comprehension of the endocannabinoid involvement in lipid metabolism, so far exclusively studied only on mammals. 


\section{Legends}

Fig. 1 CB1 gene expression in zebrafish larvae exposed to AEA or AEA+AM251 at hatching time (A), $7 \mathrm{dpf}(\mathrm{B})$ and $15 \mathrm{dpf}(\mathrm{C})$. Different letters indicate significant differences $(p<0,05)$.

Fig. 2 CB1 gene expression in the liver of adult zebrafish exposed to AEA 10 or $100 \mathrm{nM}$ and to AM251. Different letters indicate significant differences $(p<0,05)$.

Fig. 3 IGF-1 gene expression in zebrafish larvae exposed to AEA at hatching time (A), 7 $\mathrm{dpf}(\mathrm{B})$ and $15 \mathrm{dpf}(\mathrm{C})$. Different letters indicate significant differences $(p<0,05)$.

Fig. 4 IGF-2 gene expression in zebrafish larvae exposed to AEA at hatching time (A), 7 $\mathrm{dpf}(\mathrm{B})$ and $15 \mathrm{dpf}(\mathrm{C})$. Different letters indicate significant differences $(p<0,05)$.

Fig. 5 IGF-1 (A) and IGF-2 (B) gene expression in the liver of adult zebrafish exposed to AEA 10 or $100 \mathrm{nM}$. Different letters indicate significant differences $(p<0,05)$.

Fig. 6 SREBP gene expression in zebrafish larvae exposed to AEA at hatching time (A), 7 $\mathrm{dpf}(\mathrm{B})$ and $15 \mathrm{dpf}(\mathrm{C})$. Different letters indicate significant differences $(p<0,05)$.

Fig. 7 SREBP gene expression in the liver of adult zebrafish exposed to AEA 10 or 100 $n M$. Different letters indicate significant differences $(p<0,05)$. 


\section{References}

Bensaid, M., Gary-Bobo, M., Esclangon, A., Maffrand, J.P., Le Fur, G., Oury-Donat, F., Soubrié, P., 2003. The Cannabinoid CB1 Receptor Antagonist SR141716 ncreases acrp30 mrna expression in adipose tissue of obese fa/fa rats and in cultured adipocyte cells. Mol. Pharmacol. 63, 908-914.

Bouaboula, M., Hilairet, S., Marchand, J., Fajas, L., Le Fur, G., Casellas, P., 2005.

Anandamide induced PPARy transcriptional activation and 3T3-L1 preadipocyte

differentiation. European Journal of Pharmacology 517, 174-181.

Braissant, O., Wahli, W., 1997. Differential Expression of Peroxisome ProliferatorActivated Receptor-\{alpha\}, $-ß$, and -\{gamma\} during Rat Embryonic Development. Endocrinology 139, 2748-2754.

Burstein, S., 2005. PPAR-y: A nuclear receptor with affinity for cannabinoids. Life Sciences 77, 1674-1684.

Carnevali, O., Cardinali, M., Maradonna, F., Parisi, M., Olivotto, I., Polzonetti-Magni, A.M., Mosconi, G., Funkenstein, B. 2005. Hormonal regulation of hepatic IGF-I and IGF-II gene expression in the Marine Teleost Sparus aurata. Molecular Reproduction and Development 71, 12-18.

Chen, Y., Capron, L., Magnusson, J.O., Wallby, L.A., Arnqvist, H.J., 1998. Insulin-like growth factor-1 stimulates vascular smooth muscle cell proliferation in rat aorta in vivo. Growth Horm. IGF Res. 8, 299-303.

Cota, D., Morsicano, G., Tschoep, M., Gruebler, Y., Flachskamm, C., Schubert, M., Auer, D., Yassouridis, A., Thone-Reineke, C., Ortmann, S., Tomassoni, F., Cervino, C., Nisoli, E., Linthorst, A.C., Pasquali, R., Lutz, B., Stalla, G.K., Pagotto, U., 2003. The 
endogenous cannabinoid system affects energy balance via central orexigenic drive and peripheral lipogenesis. J. Clin Invest. 112, 423-431.

Dai, J.L., Burnstein, K.L., 1996. Two androgen response elements in the androgen receptor coding region are required for cell-specific up-regulation of receptor messenger RNA. Mol. Endocrinol. 10, 1582-1594.

Fu, J., Oveisi, F., Gaetani, S., Lin, E., Piomelli, D., 2005. Oleoylethanolamide, an endogenous PPAR-alpha agonist, lowers body weight and hyperlipidemia in obese rats. Neuropharmacology 48, 1147-1153.

Grimaldi, P.A., 2007. Peroxisome proliferator-activated receptors as sensors of fatty acids and derivatives. Cell. Mol. Life Sci. 64, 2459-64.

Guzman, M., Fernandez-Ruiz, J.J., Sanchez, C., Velasco, G., Ramos, J.A., 1995. Effects of anandamide on hepatic fatty acid metabolism. Biochem. Pharamacol. 7, 885-888.

Huy, N.D., Gailis, L., Cote, G., Roy, P.E., 1975. Effects of chronic administration of delta 9transtetrahydrocannabinol (delta9-THC) in guinea-pigs. Int. J. Clin. Pharmacol. Biopharm. 12, 284-289.

Jones, J.I., Clemmons, D.R., 1995. Insulin-like growth factors and their binding proteins: biological actions. Endocrine Reviews 16, 3-33.

Kunos, G., Osei-Hyiaman, D., Wang, L., Liu, J., Batkai, S., 2002. Endocannabinoids: novel lipid mediatore in the neural control of appetite. In: Medeiros-Neto G., Halpern, A., Bouchard, C. (ed.), Progress in obesity research, John Libbery Eurotext. Surrey, United Kingdom, 9, 826-828.

Lichtman, A.H., Cravatt, B.F., 2005. Food for thought: endocannabinoid modulation of lipogenesis. Clin. Invest. 115, 1130-1133.

Liu, Y.L., Connoley, I.P., Wilson, C.A., Stock, M.J., 2005. Effects of the cannabinoid CB1 receptor antagonist SR141716 on oxygen consumption and soleus muscle glucose uptake in Lepob/Lepob mice. International Journal of Obesity 29, 183-187. 
McLaughlin, C.L., Baile, C.A., Bender, P.E., 1979. Cannabinoids and feeding in sheep. Psychopharmacology 64, 321-323.

McPartland J.M., Matias, I., Di Marzo, V., Glass, M. 2006. Evolutionary origins of the endocannabinoid system. Gene 370, 29, 64-74.

Meucci, V., Arukwe, A., 2006. The environmental estrogen, 4-nonylphenol modulates brain estrogen-receptor- and aromatase (CYP19) isoforms gene expression patterns in Atlantic salmon (Salmo salar). Marine Environmental Research 62, 195-199.

Migliarini, B., Marucci, G., Guelfi, F., Carnevali, O., 2006. Cannabinergic system in Xenopus laevis development: CB1 receptor dynamics. FEBS Letters 580, 19411945.

Mortensen, A.S., Arukwe, A., 2007. Effects of 17 -ethynylestradiol on hormonal responses and xenobiotic biotransformation system of Atlantic salmon (Salmo salar). Aquatic Toxicology 85, 113-123.

Osei-Hyiaman, D., DePetrillo, M., Pacher, P., Liu, J., Radaeva, S., Batkai, S., HarveyWhite, J., Mackie, K., Offerta`ler, L., Wang, L. and Kunos, C., 2005. Endocannabinoid activation at hepatic CB1 receptors stimulates fatty acid synthesis and contributes to diet-induced obesity. J. Clin. Invest. 115, 1298-1305.

Poirier, B., Bidouard, J.P., Cadrouvele, C., Marniquet, X., Staels, B., O'Connor, S.E., Janiak, P., Herbert, J.M., 2005. The anti-obesity effect of rimonabant is associated with an improved serum lipid profile. Diabetes, Obesity and Metabolism 7, 65-72.

Pottinger, T.G., 1990. The effect of stress and exogenous cortisol on receptor-like binding of cortisol in the liver of rainbow trout, Oncorhynchus mykiss. Gen. Comp. Endocrinol. 78, 194-203.

Qi, Y., Takahashi, N., Hileman, S.M, Patel, H.R., Berg, A.H., Pajvani, U.B, Scherer, P.E., Ahima, R.S., 2004. Adiponectin acts in the brain to decrease body weight. Nat. Med. 10, 524-529. 
Ravinet Trillou, C., Arnone, M., Delgorge, C., Gonalons, N., Keane, P., Maffrand, J., Soubrié, P., 2003. Anti-obesity effect of SR141716, a CB1 receptor antagonist, in diet-induced obese mice. Am. J. Physio.I Regul. Integr. Comp. Physiol. 284, 345353.

Ravinet Trillou, C., Delgorge, C., Menet, C., Arnone, M., Soubrié, P., 2004. CB1 cannabinoid receptor knockout in mice leads to leanness, resistance to diet-induced obesity and enhanced leptin sensitivity. Int. J. Obes. 28, 640-648.

Russo, R., LoVerme, J., La Rana, G., D'Agostino, G., Sasso, O., Malignano, A., Piomelli, D., 2007. Synergistic antinociception by the cannabinoid receptor agonist anandamide and the PPAR-alpha receptor agonist GW7647. Eur. J. Pharmacol. 566, 117-9.

Seeley, R.J., Woods, S.C., 2003. Monitoring of stored and available fuel by the CNS: implications for obesity. Nat. Rev. Neurosi. 4, 901-909.

Villeneuve, L., Gisbert, E., Le Delliou, H., Cahu, C.L., Zambonino Infante, J.L., 2004. Expression and localization of some retinoid receptors durino European sea bass (Dircentrarchus labrax) larvae development. Aquaculture 242, 537-551.

\section{Acknowledgments:}

This work has been supported by COFIN 2005 awarded to Prof. Oliana Carnevali.

The authors wish to thank Dr. Chiara Piccinetti for her support in processing data and writing the manuscript. 

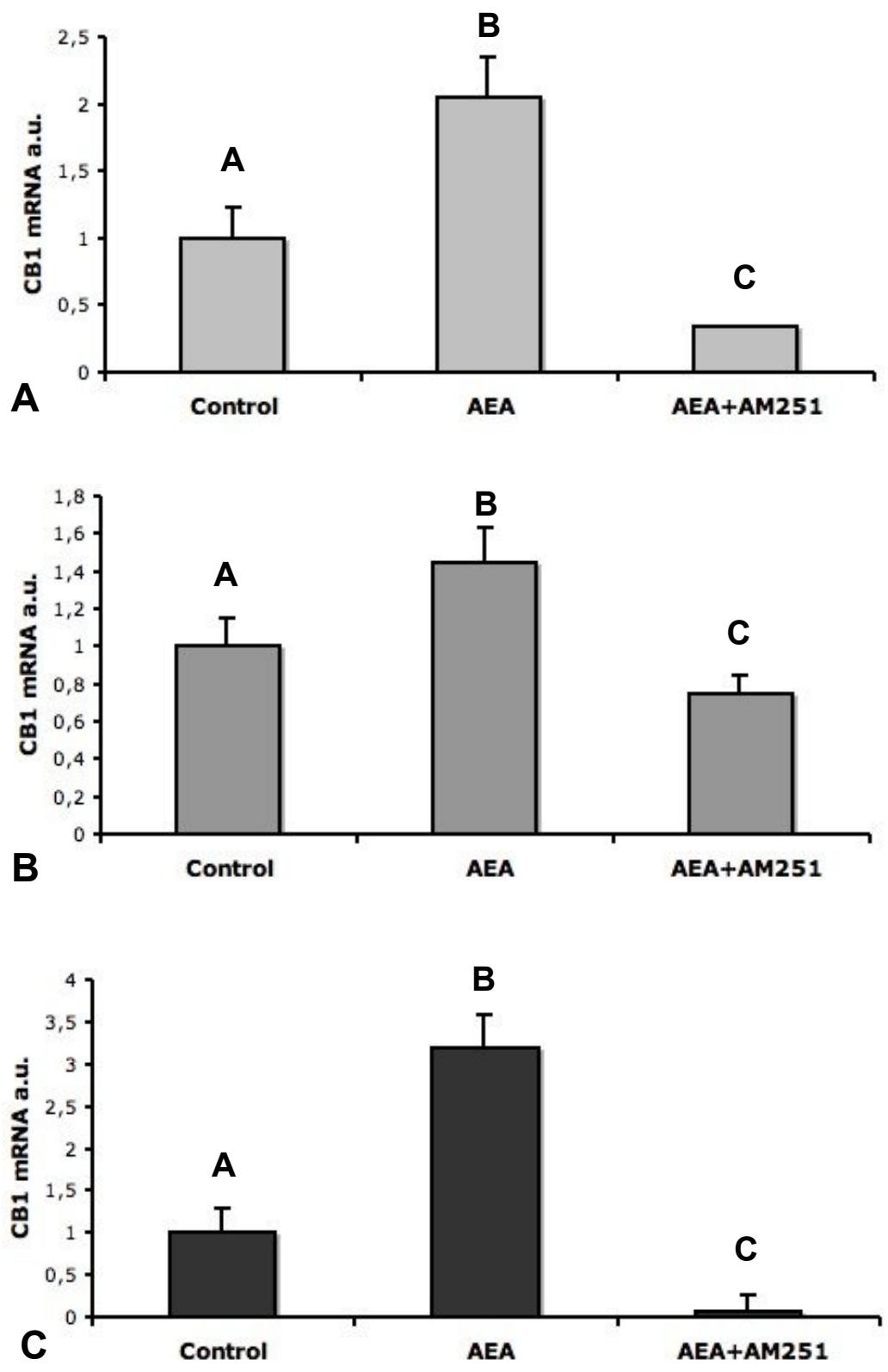


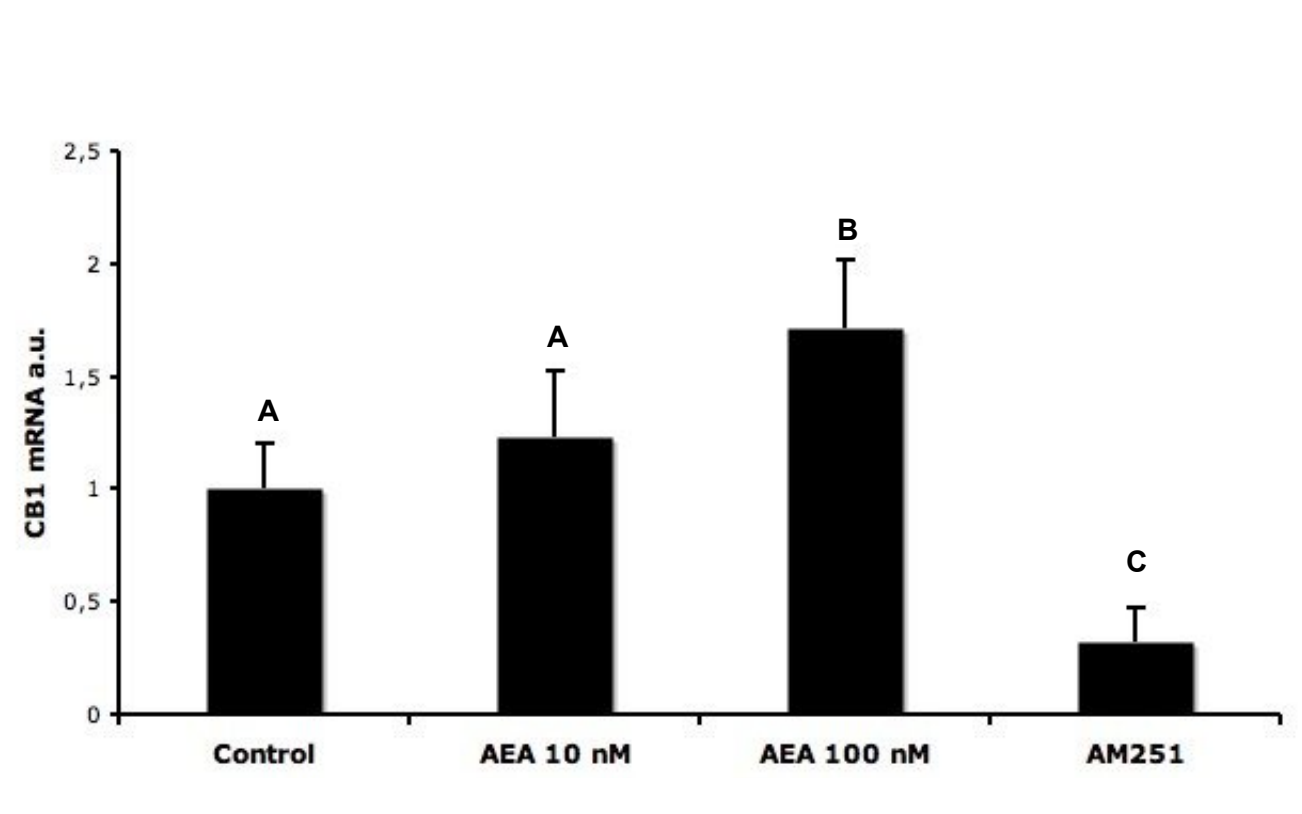

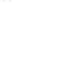

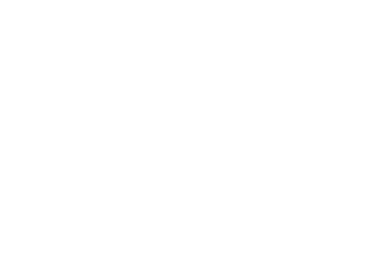



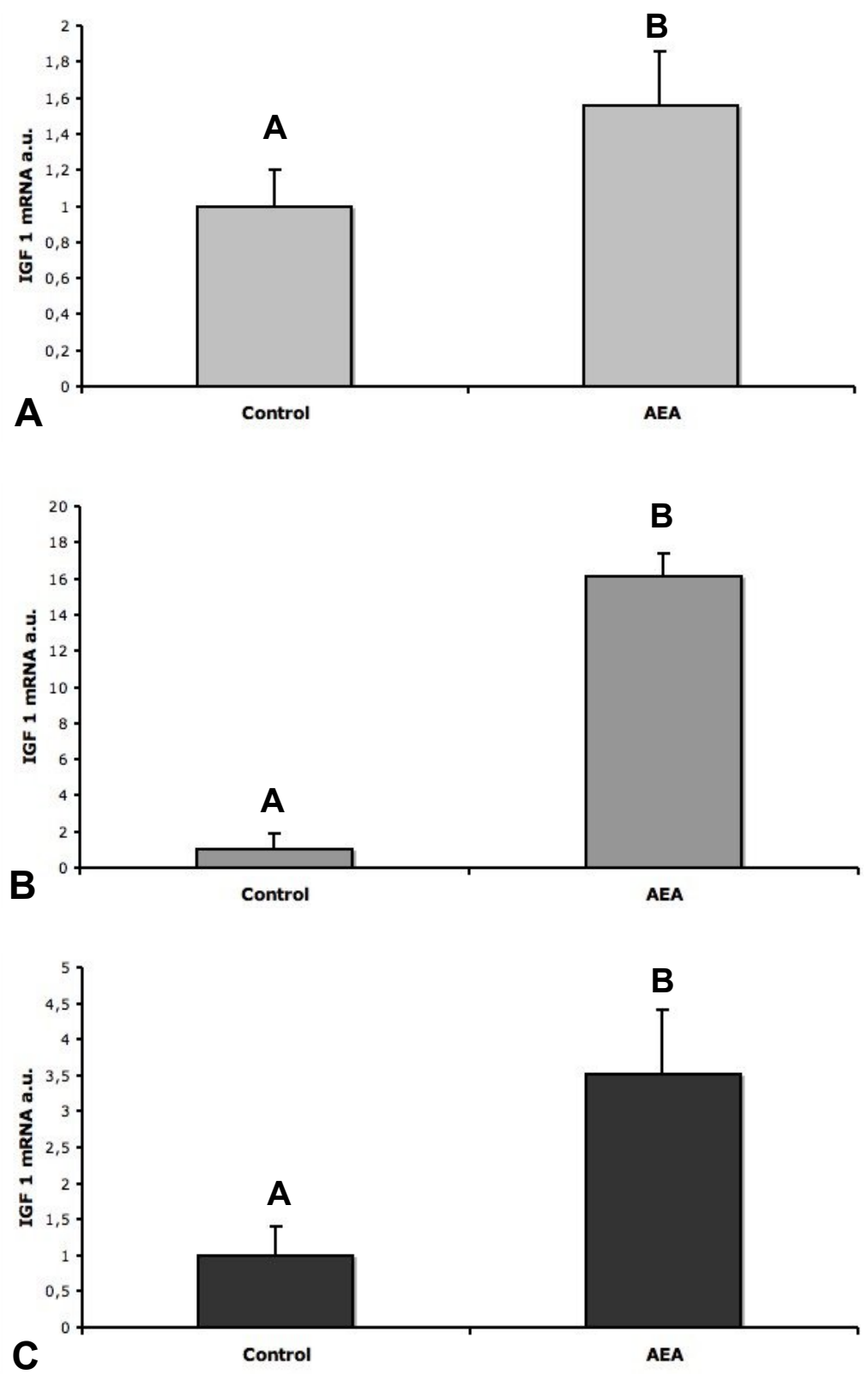

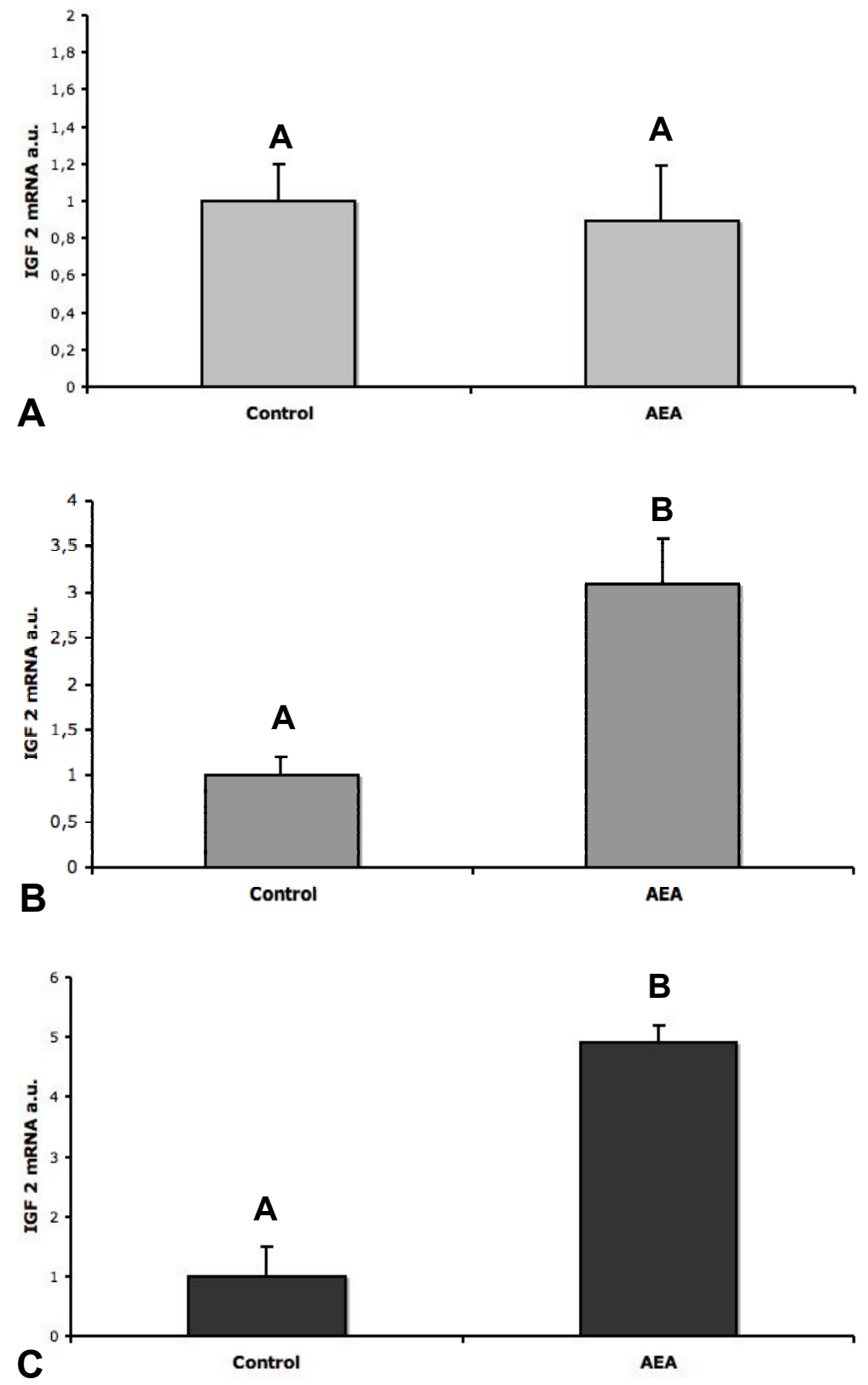

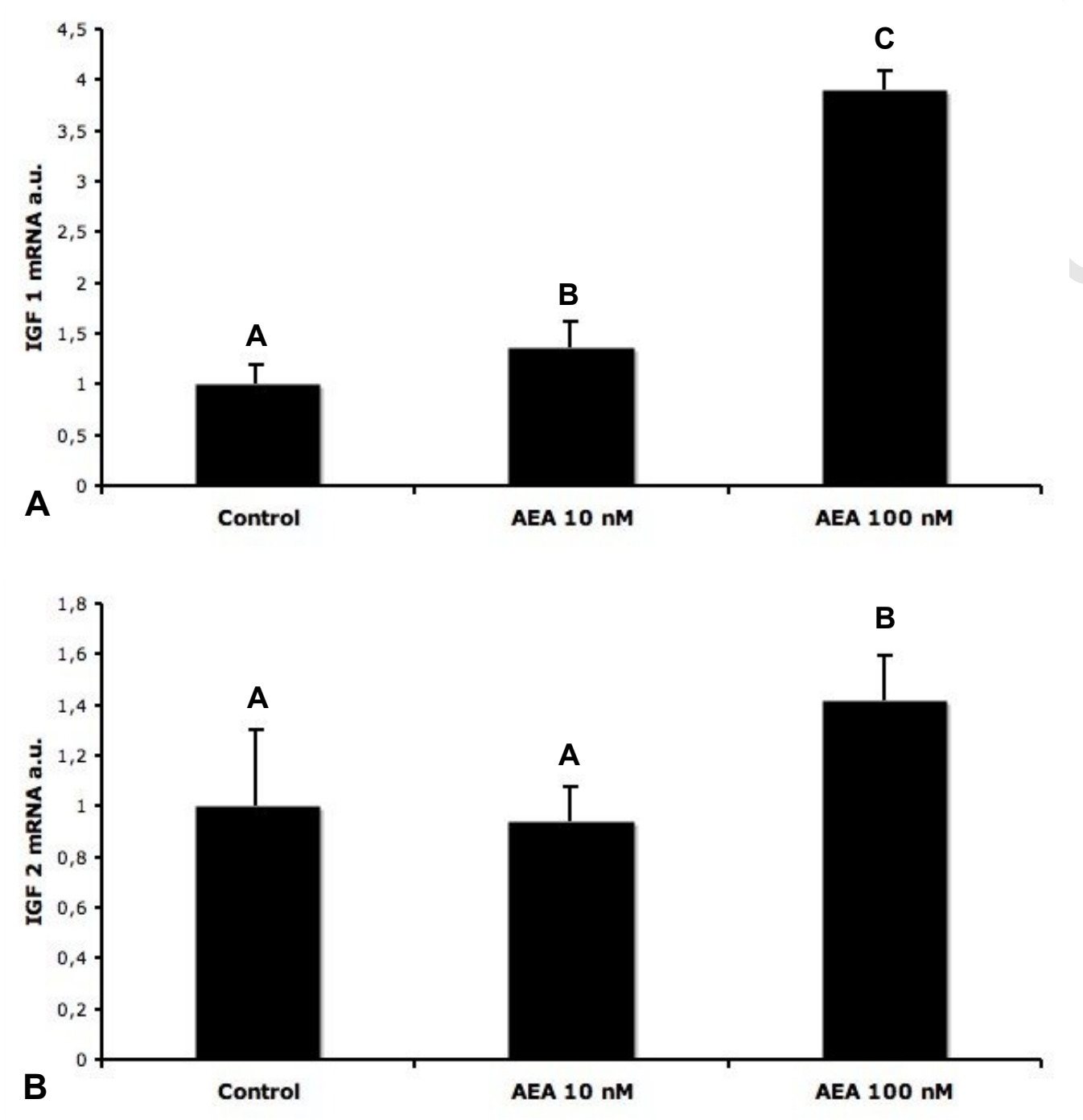
Control AEA $10 \mathrm{nM}$ 

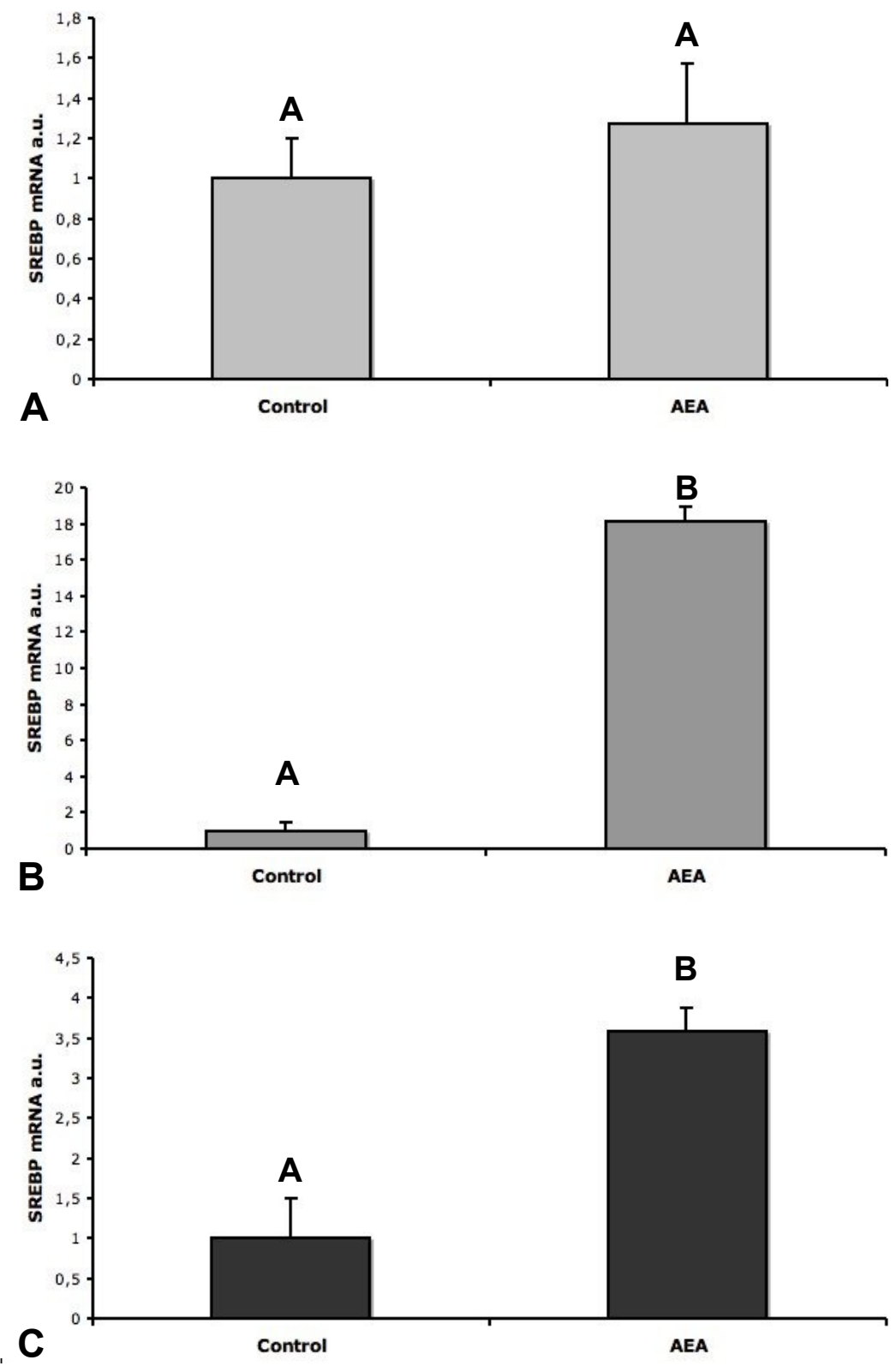


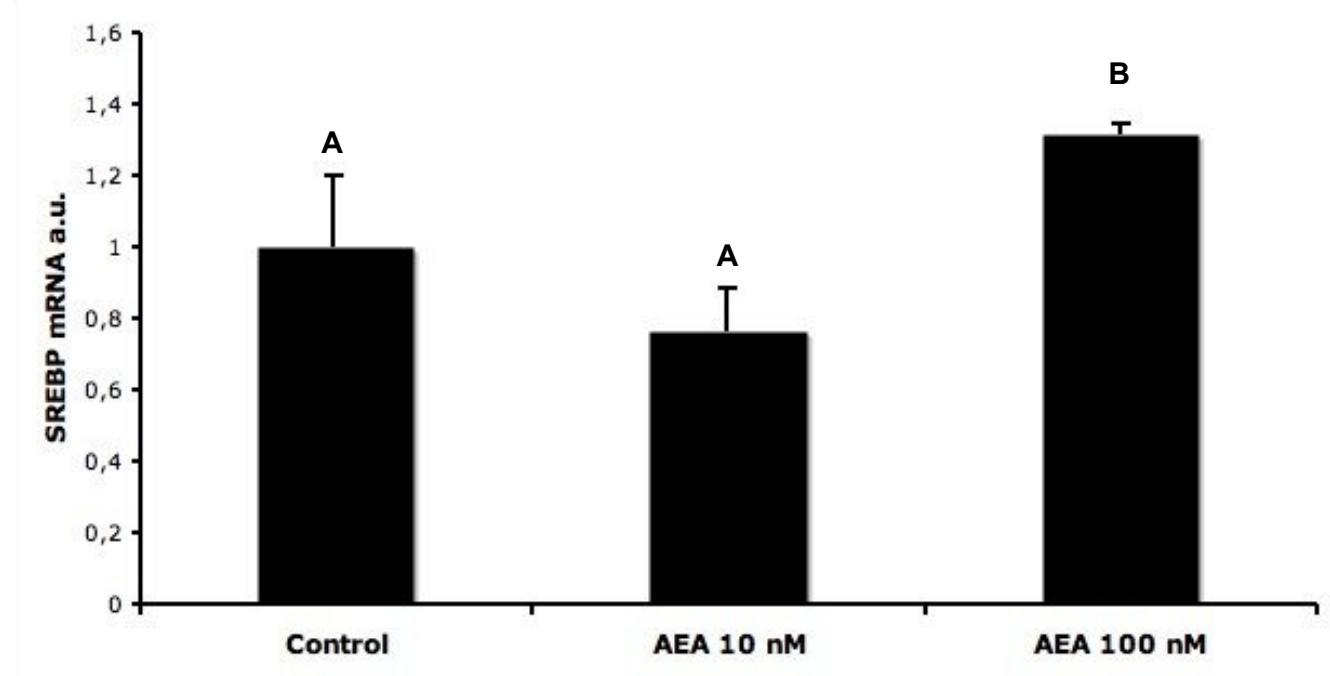

